\title{
Plasmodium falciparum resistance to artemisinin-based combination therapies: A sword of Damocles in the path toward malaria elimination
}

\author{
Manel Ouji ${ }^{1,2}$, Jean-Michel Augereau ${ }^{1,2}$, Lucie Paloque ${ }^{1,2, *}$, and Françoise Benoit-Vical ${ }^{1,2, *}$ \\ ${ }^{1}$ LCC (Laboratoire de Chimie de Coordination du CNRS), BP 44099, 205 Route de Narbonne, 31077 Toulouse cedex 4, \\ France \\ ${ }^{2}$ Université de Toulouse; UPS, INPT; LCC; F-31077 Toulouse, France
}

Received 12 February 2018, Accepted 15 March 2018, Published online 20 April 2018

\begin{abstract}
The use of artemisinin-based combination therapies (ACTs), which combine an artemisinin derivative with a partner drug, in the treatment of uncomplicated malaria has largely been responsible for the significant reduction in malaria-related mortality in tropical and subtropical regions. ACTs have also played a significant role in the $18 \%$ decline in the incidence of malaria cases from 2010 to 2016 . However, this progress is seriously threatened by the reduced clinical efficacy of artemisinins, which is characterised by delayed parasitic clearance and a high rate of recrudescence, as reported in 2008 in Western Cambodia. Resistance to artemisinins has already spread to several countries in Southeast Asia. Furthermore, resistance to partner drugs has been shown in some instances to be facilitated by pre-existing decreased susceptibility to the artemisinin component of the ACT. A major concern is not only the spread of these multidrug-resistant parasites to the rest of Asia but also their possible appearance in Sub-Saharan Africa, the continent most affected by malaria, as has been the case in the past with parasite resistance to other antimalarial treatments. It is therefore essential to understand the acquisition of resistance to artemisinins by Plasmodium falciparum to adapt malaria treatment policies and to propose new therapeutic solutions.
\end{abstract}

Keywords: malaria, artemisinin, drug resistance, parasite, Plasmodium falciparum

Résumé - Résistance de Plasmodium falciparum aux combinaisons thérapeutiques à base d'artémisinine : une épée de Damoclès sur les stratégies d'éradication du paludisme. L'utilisation, dans le traitement du paludisme simple, de combinaisons thérapeutiques associant un dérivé de l'artémisinine et une molécule partenaire a largement contribué à une réduction significative de la mortalité due à cette pathologie dans les régions tropicales et subtropicales ainsi qu'une diminution de $18 \%$ de nombre de cas de 2010 à 2016. Cependant, ces progrès sont sérieusement menacés par la diminution de l'efficacité clinique des artémisinines caractérisées par des clairances parasitaires retardées et un taux de recrudescence élevé, signalés en 2008 à l'ouest du Cambodge. La résistance aux artémisinines s'est déjà étendue à plusieurs pays d'Asie du Sud-Est. De plus, il a été montré que la résistance aux molécules partenaires des artémisinines dans ces combinaisons thérapeutiques $(\mathrm{ACT})$ a été facilitée suite à une diminution de la sensibilité à l'artémisinine. L'une des principales préoccupations est non seulement la propagation de ces parasites multirésistants dans le reste de l'Asie, mais aussi leur apparition possible en Afrique subsaharienne, continent le plus touché par le paludisme, comme cela a été le cas dans le passé avec la résistance de parasites à d'autres traitements antipaludiques. Il est donc essentiel de comprendre l'acquisition de la résistance de Plasmodium falciparum aux artémisinines afin d'adapter les politiques de santé face au paludisme et de proposer de nouvelles solutions thérapeutiques.

\footnotetext{
*Corresponding authors: lucie.paloque@lcc-toulouse.fr;

Francoise.Vical@inserm.fr
} 


\section{Main mechanisms of Plasmodium falciparum resistance}

Two main mechanisms of resistance drive Plasmodium resistance to antimalarial drugs. The first one is an efflux of the drug away from its action site due to mutations in different transporter genes (like pfcrt in chloroquine resistance) or an increased number of the gene copies (like $p f m d r 1$ copy number in mefloquine resistance). The second is a change in the parasite target due to mutations in corresponding genes (like, at the cytosol level, dhfr and dhps in sulfadoxine-pyrimethamine resistance or, at the mitochondrion level, cytochrome $\mathrm{b}$ in atovaquone resistance). Surprisingly, resistance of falciparum malaria to the new artemisinin compounds involves a novel mechanism corresponding to a quiescence phenomenon.

\section{Introduction}

Malaria is widespread in countries located in tropical and sub-tropical regions, where an estimated 3.2 billion people, nearly half of the world's population, are at risk of infection [79]. Among the five species of Plasmodium that infect humans, Plasmodium falciparum is the most virulent, with the highest rates of complications and mortality as well as the most frequent incidence of red blood cell disorders worldwide [12]. Of the estimated 216 million cases in 2016, falciparum malaria accounted for $99 \%$ of cases in Africa, $77 \%$ of cases in the Western Pacific Region, $66 \%$ of cases in Southeast Asia, $58 \%$ of cases in the Eastern Mediterranean Region, and 36\% of cases in America [79]. Over $91 \%$ of the estimated 445000 global deaths from malaria in 2016 occurred in Sub-Saharan Africa, primarily among children less than five years of age $[13,79]$. Over the last 17 years, important measures have been put in place to prevent malaria, leading to a $60 \%$ reduction in its worldwide death toll. A decrease of $18 \%$ in the incidence of malaria cases was also reported from 2010 to 2016 [79]. This significant decrease in malaria incidence is the result of both preventive measures, such as the massive distribution of insecticide-treated nets, vector control strategies, and rapid diagnostic tests, as well as the use of artemisinin-based combination therapies (ACTs) in curative therapy. ACTs, recommended by the World Health Organization (WHO), are currently used as the first-line antimalarial treatment worldwide [79]. However, the current efforts to reduce the global burden of malaria are threatened by the rapid emergence and spread of $P$. falciparum resistance to ACTs including artemisinin derivatives and their partner drugs.

\section{Artemisinin and $\mathrm{ACT}$ s}

The 2015 Nobel Prize in Medicine was awarded to Professor Tu Youyou for her key contribution to the discovery of artemisinin. Artemisinin, isolated from the plant Artemisia annua, and its semi-synthetic derivatives (artemether, artesunate, dihydroartemisinin) are powerful medicines known for their ability to swiftly reduce the number of Plasmodium parasites in the blood of patients suffering from malaria [2]. The unique characteristic of artemisinins is that they clear parasitemia more rapidly than all other antimalarials, including quinine [21]. Their efficacy can be ascribed to the fact that these compounds target not only the late erythrocytic parasite stages, like most antimalarial drugs, but also the early stages. Artemisinins, by killing the ring stage forms, allow the parasite to be pitted out of the host red blood cells, hence removing them from circulation $[12,51,78]$ and preventing these parasite stages from maturing and sequestering in the vessels. This phenomenon is important in the pathogenesis because mature parasites are able to adhere to endothelial cells, blood cells and platelets which prevent their circulation in the bloodstream and they will therefore be able to escape retention by the spleen [12].

In the parasitic food vacuole, artemisinins react with haem that is generated from the digestion of haemoglobin and is toxic to the parasite, to form haem-artemisinin adducts [67]. These adducts seem to interact with $P$. falciparum haem detoxification proteins and inhibit haemozoin polymerisation leading to haem accumulation. Artemisinins are also responsible for alkylation of parasite proteins. Together, these events cause oxidative stress, leading to irreversible parasite damage and parasite death [17]. This explains the life-saving benefit of artemisinins and elucidates the mechanism underlying their superior efficacy for the treatment of malaria [21]. Artemisinins also reduce the number of gametocytes (sexual-stage parasites) responsible for its transmission to the vector, the Anopheles mosquito [2], both with direct antigametocyte activity and indirect action via the reduction of the asexual parasite population, which is the source of new gametocytes [18].

Since 1994, artemisinins have been used in ACTs to treat uncomplicated malaria. ACTs combine 2 active ingredients, artemisinins and another antimalarial drug, with different mechanisms of action. It has been reasoned that in ACTs, the partner drugs are chosen on the basis of their pharmacokinetic properties, which include much longer plasma half-lives (days to weeks) than those of artemisinins ( 1 to $2 \mathrm{~h}$ ). While artemisinins are eliminated very rapidly from the body, the remaining parasites are exposed to the associated long-acting drug well after the end of the usual 3-day ACT course [80]. ACTs are the most effective antimalarial medicines available today, and they have replaced quinolines and antifolates as the first-line treatment for uncomplicated P.falciparummalaria in most endemic countries.

Five ACTs are currently used (Table 1), namely, artemether/lumefantrine (AL), artesunate/amodiaquine (ASAQ), artesunate/mefloquine (ASMQ), artesunate/ sulfadoxine/pyrimethamine $(\mathrm{AS}+\mathrm{SP})$ and dihydroartemisinin/piperaquine (DHA/PPQ) [80]. A sixth ACT, artesunate/pyronaridine [47], was recently approved, and 
M. Ouji et al.: Parasite 2018, 25, 24

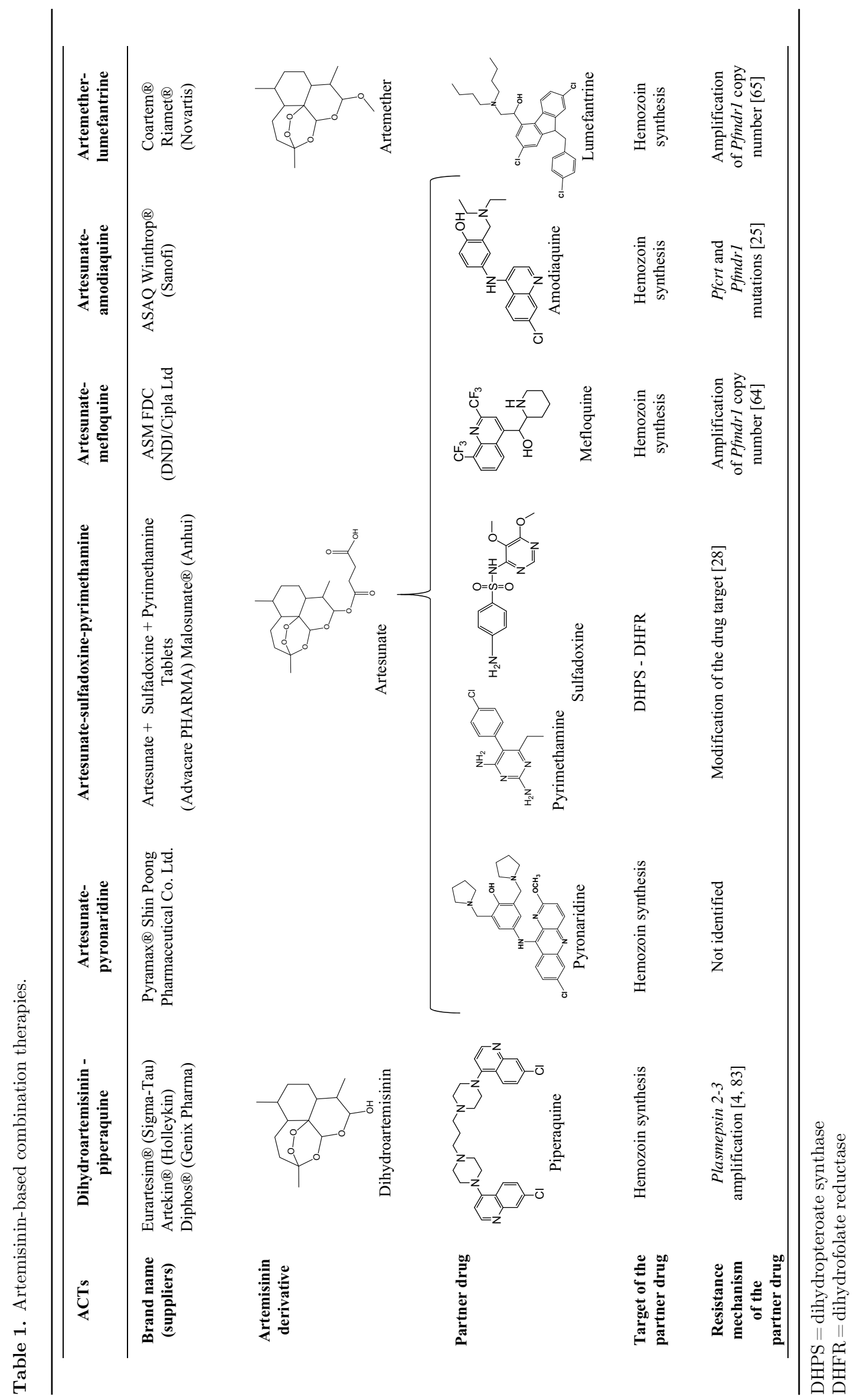




\section{PfK13 (726 aa)}

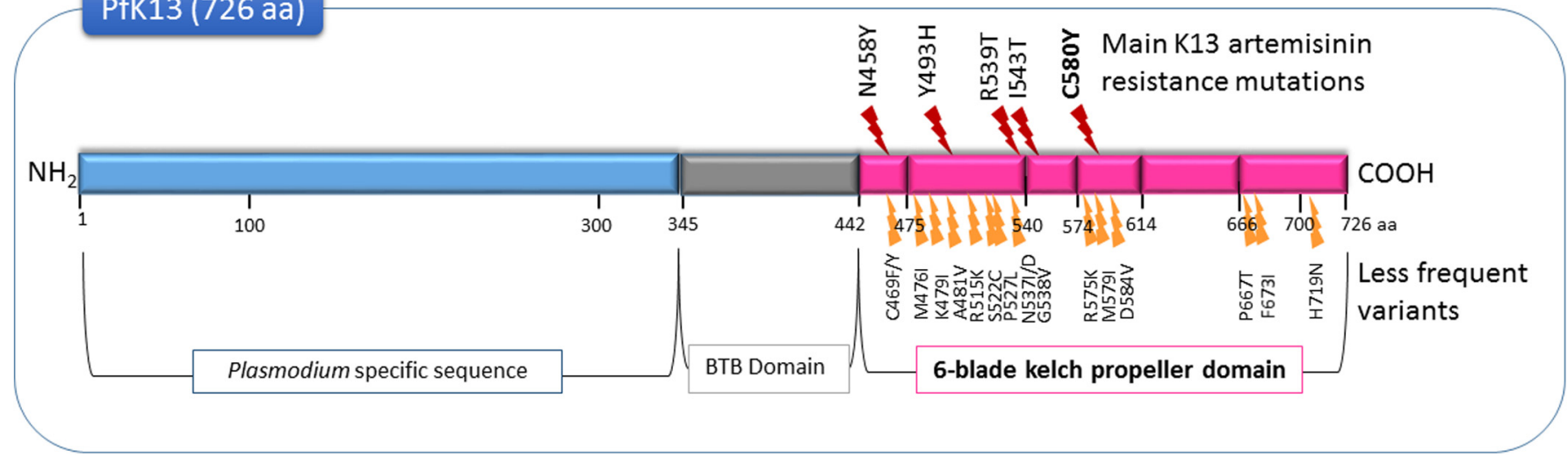

Figure 1. Mutations in the PfK13 protein involved in artemisinin resistance (WHO) [80].

unfortunately, its current efficacy on day 42 was below 90\% in Western Cambodia, an artemisinin-resistance area [38]. In 2016, 409 million ACT-based treatments were applied worldwide [79].

Malaria treatment in pregnant women presents substantial risks for the mother and the unborn child. The risk-free use of artemisinin derivatives has not been well established in the first trimester of pregnancy [27], which is why the WHO does not recommend the use of these drugs during this period. Nevertheless, treatment with artemisinins during the second and third trimesters has been shown to be safe and does not have greater risks than other antimalarial drugs during these periods [32].

\section{Artemisinin resistance: definition}

Artemisinin resistance was documented in 2008 on the Thailand-Cambodia border after artesunate monotherapy $[22,53]$. However, retrospective analysis indicates that artemisinin resistance likely emerged in 2001, before the widespread deployment of ACTs in Cambodia [81]. Artemisinin resistance was first correlated with delayed parasitic clearance after the first 3 days of treatment following artemisinin monotherapy or ACTs and higher rates of clinical failures due to increased parasitic recrudescence [22,53]. Increased clearance half-life was highly correlated with greater recrudescence rates in vivo after artemisinin elimination, which means that the parasites survive artemisinin treatment and are able to continue their development after the elimination of artemisinin from the body. Parasite clearance half-life is the time required to physiologically reduce the parasitemia by $50 \%$ following an administered antimalarial dose. Nevertheless, most patients who have delayed parasite clearance following treatment with an ACT are still able to clear their infection, as long as the partner drug remains effective. That is why delayed parasite clearance does not necessarily lead to treatment failure, even though artemisinin resistance can promote selection of the concomitant resistance to the partner drug.

Usually, in the resistance to other malaria drugs, the parasites are able to proliferate and multiply during treatment, but the same is not true in the case of artemisinin resistance. The resistance to artemisinin is based on a mechanism of entry into quiescence that occurs only at the ring stage. This finding was revealed by an experimental model, the F32-ART5 parasite line (a highly artemisinin-resistant strain established in vitro after 5 years of exposure to sequential and escalating concentrations of artemisinin reaching 7000 -fold the $\mathrm{IC}_{50}$ value of the parental and sensitive F32-Tanzania strain) and was confirmed with Cambodian P. falciparum isolates [84,85]. As artemisinin resistance is due to the quiescent state of parasites in the presence of artemisinins [55], the standard in vitro chemosensitivity assays recommended by the WHO $[19,22]$ to evaluate the antimalarial drug inhibition of parasite growth are not reliable tools for monitoring artemisinin resistance. The resistance to artemisinin is evidenced ex vivo or in vitro by the Ring stage Survival Assay $\left(\mathrm{RSA}^{0-3 \mathrm{~h}}\right)$, which is based on $6 \mathrm{~h}$ of $700 \mathrm{nM}$ dihydroartemisinin exposure in highly synchronised $P$. falciparum parasites at the ring stage and is followed by culture in drug-free conditions until the microscopic read-out at $72 \mathrm{~h}$ [84].

At a molecular level, a comparison of the whole genome sequence of F32-ART5 and of its twin sensitive parasite line, F32-TEM, demonstrated that a mutation in the propeller domain of the gene encoding Kelch protein 13 (K13) was associated with artemisinin resistance [6]. The exact function of this protein is not yet known, but it shares homologies with the human Keap1 protein, involved in the cell response to oxidative stress $[6,1]$. K13 is localised in the reticulum endoplasmic of the parasite [9].

Other non-synonymous mutations, all present after position 440 in the propeller domain of the $p f k 13$ gene (Figure 1), were also associated with artemisinin resistance in the field and were confirmed in laboratory experiments [80]. Only one of these mutations is sufficient to confer this resistance. However, not all reported nonsynonymous propeller-domain K13 mutants indicate the emergence of artemisinin resistance [26]. That is why the relevance of a new $p f k 13$ mutation as a molecular marker of artemisinin resistance must be validated by clinical data and genetic engineering [79]. The high survival rate of parasites in $\mathrm{RSA}^{0-3 \mathrm{~h}}$ correlates with both $p f k 13$ polymorphisms and clinical outcomes $[6,74,80]$. 
In summary, according to the WHO, artemisinin resistance is currently defined by delayed parasite clearance time at a clinical level, by a high survival rate of parasites in the Ring stage Survival Assay $\left(\mathrm{RSA}^{0-3 \mathrm{~h}}\right)$ ex vivo or in vitro, and by polymorphism of the $p f k 13$ gene [80].

\section{Current situation of $\boldsymbol{P}$. falciparum resistance to artemisinins and to ACTs}

At the present time, artemisinin resistance is limited to the Greater Mekong subregion, i.e., Cambodia, Thailand, Lao People's Democratic Republic (Lao PDR), Myanmar, Viet Nam, and the Myanmar-China-India border area $[77,80]$. It has been demonstrated that artemisinin resistance has not only spread across this region but has also arisen independently several times in different locations $[43,75]$. ACTs were implemented to contain clinical resistance after artemisinin monotherapy, based on the different mechanistic and pharmacokinetic properties of the two combined antimalarials. Unfortunately, even though artemisinin resistance leads to few real clinical failures, it promotes selection for partner-drug resistance mainly due to mismatches in the pharmacokinetics of the two drugs, causing frequent treatment failure of ACTs [3]. An increase in concomitant artemisinin and partner drug resistances has been observed in recent years and, as a consequence, treatment failures after ACTs are becoming more widespread in Southeast Asia $[24,39,50]$. However, outside the Greater Mekong subregion, treatment failure with ACTs has occurred in the absence of artemisinin resistance mainly due to partner drug resistance [80].

In Southeast Asia, the first ACT was implemented in 1994 (artesunate-mefloquine (ASMQ) introduction in a refugee camp at the Thailand-Myanmar border [60]), before the WHO started recommending the use of ACTs as firstline antimalarial treatment in 2001. In 2006, the declining efficacy of ASMQ was suspected for the first time on the Cambodia-Thailand border [86]. Thereafter, ASMQ clinical failures were reported on the Thailand-Myanmar border in correlation with delayed parasite clearance time [50] and the amplification of pfmdr1 gene copy numbers [48,58]. In addition, a prospective study conducted between 2003 and 2013 showed that the increasing prevalence of pfk13 mutations was the decisive factor for the rapid decline in the efficacy of ASMQ on the Thailand-Myanmar border [60].

Clinical failures after dihydroartemisinin-piperaquine (DHA/PPQ) treatment have also been reported, first in Cambodia in 2013 [37] and later in Vietnam in 2017 $[59,76]$, five and twelve years, respectively, after DHA/ PPQ treatment introduction. DHA/PPQ resistance was confirmed by several reports and correlated with $p f k 13$ polymorphism, plasmepsin 2-3 gene amplification and single copies of the $p f m d r 1$ gene [4,83]. Recent data suggest that piperaquine resistance has developed in a background of artemisinin resistance $[3,29,60,68,71]$.

It is of concern that the emergence of artemisinin resistance in Southeast Asia involves severe malaria. Recently, two patients treated with artesunate, the treatment of choice for severe falciparum malaria, showed poor responses, and one patient died [63].

According to the latest WHO Malaria Report [79], an $\mathrm{ACT}$ is considered to present high risk of failure if high treatment failures for any partner drug in the corresponding ACTs are reported. Clinical failure rates greater than $10 \%$ have now been reported for the 5 ACTs in Cambodia, for 2 ACTs in Thailand and Lao PDR and for 1 ACT in Viet Nam, Myanmar, and in the Chinese and Indian border regions with Myanmar.

In such cases, the treatment must be replaced by another one, which will be evaluated every two years to adapt the treatment as quickly as possible [79]. A triple combination therapy regimen is one of the iterations of the Tracking Resistance to Artemisinin Collaboration project, known as TRAC II. This project is the first of its kind to investigate the safety, tolerability and efficacy of triple artemisinin-based combination therapies (TACTs) in clinical trials in Southeast Asia. In TACTs, the third partner drug should have an intermediate half-life so that it can provide an associative protective effect over both the fast-acting artemisinin drug and the long-acting partner drug [20,23,77].

\section{Is drug cycling an option for artemisinin resistance?}

Susceptibility to chloroquine has been restored in Malawi and Zambia, and its re-introduction long after its withdrawal will show its efficacy in the field [33-35,49]. However, this recovered sensitivity is not systematic, as shown in Venezuela, where parasites remained resistant to chloroquine more than 15 years after the cessation of the use of chloroquine [16]. Thus, the use of drug "cycling", based on alternative introductions of antimalarials to reduce the selective pressure on the parasite, has also been considered [20]. This raises several questions. Is the risk of drug resistance re-emergence too high? For how long should these cycles last, long enough so that resistance reemergence is observed? Should these drugs be recycled on a regular basis? [20]. It has been demonstrated that plasmepsin 2-3 gene amplification in DHA/PPQ resistant parasites is associated with $p f m d r 1$ gene single copies, so these resistant parasites are sensitive to mefloquine $[4,83]$. In contrast, ASMQ-resistant parasites with pfmdr1 gene amplification are sensitive to piperaquine $[3,4,24,83]$. Based on the amplification of $p f m d r 1$ gene copy numbers of ACT-resistant parasites, the alternating use of ASMQ and DHA/PPQ is under consideration.

\section{Cross-resistance extension with other antimalarials}

Artemisinin resistance is a major threat to global public health, and there is an urgent need to accelerate the elimination of $P$. falciparum in the greater Mekong subregion, where standard courses of ACTs are failing [77]. That is why malaria elimination requires, among 
other things, new, highly effective medicines. The global portfolio of antimalarial medicines contains 33 new medicines composed of various chemical entities with many mechanisms of action that have been evaluated from preclinical research to regulatory review [47]. However, new antimalarial drugs studies are highly challenged by the risk of cross-resistance with artemisinins.

How could extended artemisinin pressure affect the response of artemisinin-resistant $P$. falciparum to other antimalarial drugs in the field? It has recently been demonstrated in vitro that prolonged exposure to artemisinin induced a novel multidrug-tolerant phenotype in previously artemisinin-resistant parasites. After 5 years of artemisinin pressure, the resistant strain F32-ART5 was able to stop multiplying by entering into a quiescent state following treatment with artemisinin [85] as well as with other antimalarial drugs alone such as quinolines (amodiaquine, mefloquine, chloroquine, quinine) or pyrimethamine. Surprisingly, this pluri-resistance was not associated with any of the known genes involved in resistance to these drugs, except pfk13 [44]. Only atovaquone escaped this multi-tolerance by remaining effective in the F32-ART5 parasite line [44]. This could be explained by its mode of action, which is based on the inhibition of mitochondrial electron transfer, which is actively maintained in quiescent parasites [15,57]. Unfortunately, resistance to atovaquone is easily and quickly selected in the field, independent of artemisinin use [31].

From a pharmacological point of view, compounds with similar chemical structures and modes of action (namely, ozonides and trioxaquines) raise concerns about crossresistance. In fact, a recent laboratory study showed that artemisinin-resistant strains as well as resistant Cambodian isolates presented cross-resistance with trioxaquines (endoperoxide-based hybrid antimalarial molecules). Moreover, trioxaquine drug pressure selected in vitro a new lineage that was resistant to both trioxaquines and artemisinins, in a manner supported by pfk13 polymorphism [56].

Moreover, among the most promising medicines of the antimalarial portfolio are two ozonide compounds OZ439 and OZ277, respectively known as artefenomel and arterolane, both of which contain an endoperoxide bridge, a chemical function also found in artemisinins. Although OZ439 has shown a good safety profile in a clinical trial and rapid parasitemia clearance in $P$. falciparum (and in $P$. vivax) [61], it was recently reported that this is not the case for artemisinin-resistant strains in vitro. In fact, resistant parasites can exhibit reduced in vitro sensitivity to the ozonide antimalarials, depending on the exposure time [89]. Moreover, it has been shown that ozonide OZ277 demonstrates significantly limited in vitro activity against artemisinin-resistant parasites, while OZ439 seems effective against most $p f k 13$-mutated, artemisinin-resistant parasite lines, except for those harbouring the mutation I543T [72].

Therefore, all these data raise concerns about the risks of parasite cross-resistance between artemisinins and other endoperoxide-based antimalarials, including ozonides. Field-based resistance monitoring is indispens- able to detect any cross-resistance in artemisinin-resistance areas. Furthermore, these results highlight the importance of investigating the ability of newly developed antimalarial drugs to select for resistance based on a quiescence mechanism.

\section{Risk of worldwide spread of artemisinin resistance}

The greater Mekong subregion is the epicentre of the emergence of $P$. falciparum resistance, with the potential for it to spread to other malaria-endemic continents [46]. This regional specificity could be explained by many factors, such as host immunity levels leading to the regular use of antiplasmodial drugs, genetic parasite factors due to Plasmodium origins, poor access to drugs, and the continued use of monotherapy. Moreover, low quality and counterfeit antimalarial drugs are widespread. Recent estimates from Southeast Asia suggest that up to $50 \%$ of the artesunate sold is fake. This situation is expected to worsen in other endemic malaria countries with the implementation of ACTs, which are more expensive [30]. ACTs sold without any quality control are ubiquitous in Sub-Saharan Africa, both in the private and the public sectors. Kenya is a telling example since fake ACTs represent $20 \%$ and $5 \%$ of the antimalarial treatments sold by the country's private sector and public sector, respectively [10]. In the seven African countries audited under the ACTwatch project (Benin, Democratic Republic of Congo, Kenya, Nigeria, Tanzania, Uganda and Zambia), non-quality-assured ACTs accounted for $32 \%$ to $89 \%$ of the total ACTs used, and, surprisingly, nonquality-assured ACTs were more expensive than the quality-assured drugs [52].

The consumption of poor-quality antimalarials in SubSaharan Africa has also affected children under five years of age, with an estimated 122,350 avoidable deaths in 2013 [66]. On the other hand, the continued use of monotherapy is widely considered to be one of the main factors contributing to the development and spread of resistance. Until December 2014, eight countries, mainly in Africa (Angola, Cape Verde, Colombia, Equatorial Guinea, Gambia, Sao Tome and Principe, Somalia, and Swaziland) still offered artemisinins in monotherapy as part of their health policy, despite their ban by the WHO [82].

The grave concern of artemisinin resistance spreading from Asia is further aggravated by the history of antiplasmodial drug resistance, such as the emergence of chloroquine resistance and its spread in the 1970s [46], and by the recent report of the ability of artemisinin-resistant parasites originating from Asia to infect and be transmitted by a wide range of Anopheles species, including the main African malaria vector, Anopheles gambiae [36].

From a molecular point of view, the independent emergence of artemisinin resistance outside Asia is dependent on the role of the genetic background of the parasite. Resistance to artemisinins is heritable and therefore has a clear genetic basis $[5,62]$. Genome modification studies have shown that the impact of 
various $p f k 13$ mutations on parasitic clearance and the survival rates of ring stage parasites is dependent on the genetic background of the parasites [73]. Artemisinin resistance appears to have been selected from a population of predisposed parasites with polymorphisms of the $f d$ (ferredoxin), arps10 (apicoplast ribosomal protein S10), mdr2 (multidrug resistance protein 2) and crt (chloroquine resistance transporter) genes [45]. Another study suggested that mutations in a number of DNA repair genes such as mlh1, pms1 and exo1, are overexpressed in artemisinin-resistant parasites [40]. Together, these data indicate that the risk of emergence of new mutations causing resistance to artemisinins is promoted by specific genetic factors in a parasite population [14,45].

However, no correlation between drug resistance emergence and increased mutation rates of the parasite's genome was found in Southeast Asia, invalidating the hypothesis of a "hypermutator" parasite [11]. In contrast, evidence of a "mild mutator" phenotype has been shown in two artemisinin-resistant Cambodian isolates [40].

Spatiotemporal analysis of many isolates collected in Cambodia over the past decade has shown a gradual increase in the frequency of mutant K13 parasites in resistance-affected provinces [4,6]. However, to date, the KARMA (K13 Artemisinin Resistance Multicenter Assessment) study, analysing more than 14,000 parasite samples from 59 countries in which malaria is endemic, determined, on the basis of $p f k 13$ monitoring, that artemisinin resistance is confined to Southeast Asia and has not yet spread and/or emerged in other endemic malaria areas, i.e., Sub-Saharan Africa, South America and Oceania [43]. Only one suspected case of artemisinin resistance (associated with a non-synonymous single nucleotide polymorphism (M579I) K13 mutation) has been reported in Africa in a man who returned to China after having worked for 20 months in Guinea [41]. So far, there has been no confirmed resistance to ACTs or delayed parasite clearance during routine therapeutic efficacy studies conducted in Africa [54,70]. One study suggested that a threshold of $5 \%$ of cases on day 3 with parasite positivity is more suited to artemisinin resistance monitoring in Sub-Saharan Africa due to the higher levels of acquired immunity against Plasmodium in African populations, which contributes to faster parasite clearance [87]. Furthermore, for ACT treatments, several factors could also influence parasite clearance time values such as initial parasite biomass and partner drug efficacy, as well as, for artemisinin-sensitive areas, patient age, health status (i.e., fever with a possible relation with schizont rupture) and artemisinin dose [88]. All these data could be integrated in artemisinin-resistance emergence monitoring. Indeed, recent studies showed that low levels of immunity are correlated with a high prevalence of $p f k 13$ mutations across the greater Mekong subregion. This may be due to a drug pressure-independent mechanism that could be linked to the fitness of resistant or wild-type parasitic populations, depending on levels of immunity and transmission $[7,8]$. Moreover, the emergence of $p f k 13$ mutations in Asia was preceded by a gradual decrease in both transmission and immunity in the previous 6 years [8]. In South America and Oceania, the absence of artemisinin resistance may also be explained by the more recent introduction of ACTs.

To date, Africa is an area with a high malaria transmission rate and high naturally acquired immunity. However, with the support of the WHO programme (Global Technical Strategy for Malaria 2016-2030), the progress made by countries in malaria elimination and the decrease in malaria incidence are expected to be associated with a decrease in immunity levels, which may provide conditions conducive to the emergence of artemisinin resistance. If resistance to artemisinin and ACTs were to emerge in Africa, where $90 \%$ of deaths occur [79], this could have a devastating impact on malaria-related morbidity and mortality.

Across Africa, it is estimated that if ACT resistance were similar to the highest levels of artemisinin and partner drug resistance currently observed in Cambodia, there would be 78 million additional clinical malaria cases between 2016 and 2020 [69]. Medical costs for the treatment of clinical failures and for the management of severe malaria will also increase. The spread and/or emergence of artemisinin and ACTs resistance will also lead to a loss of productivity resulting from excess morbidity and mortality [42].

Based on these results, it is important to pay considerably more attention to control of the emergence of artemisinin resistance and to invest greater resources than those currently being made available.

\section{Conclusion}

The emergence of resistant parasites to both artemisinins and partner drugs, as well as the lack of the shortterm availability of effective alternative antimalarial drugs, are of great concern in the fight against malaria. Furthermore, the development of multi-tolerance by $P$. falciparum in the field, which has also been demonstrated in vitro after several years of drug pressure with artemisinin alone, should be a major concern for government and international authorities. Although there is no current evidence that artemisinin resistance has emerged outside Asia, this finding reinforces the need for routine monitoring and surveillance of the therapeutic efficacy and safety of artemisinins and ACTs, as recommended by the WHO, for effective case management and early detection of resistance. This artemisinin resistance monitoring should include the proportion of patients with early treatment failure, late clinical failure or any inadequate clinical response, the differentiation between recrudescence and new infection, the polymorphism of the molecular marker K13, and the in vitro susceptibility of $P$. falciparum isolates to artemisinins by relevant assays.

\section{Conflicts of Interest}

The authors declare that they have no conflicts of interest in relation to this article. 


\section{References}

1. Adams J, Kelso R, Cooley L. 2000. The kelch repeat superfamily of proteins: propellers of cell function. Trends in Cell Biology, 10, 17-24.

2. Adjuik M, Babiker A, Garner P, Olliaro P, Taylor W, White N, International Artemisinin Study Group. 2004. Artesunate combinations for treatment of malaria: meta-analysis. Lancet, 363, 9-17.

3. Amaratunga C, Lim P, Suon S, Sreng S, Mao S, Sopha C, Sam B, Dek D, Try V, Amato R, Blessborn D, Song L, Tullo GS, Fay MP, Anderson JM, Tarning J, Fairhurst RM. 2016. Dihydroartemisinin-piperaquine resistance in Plasmodium falciparum malaria in Cambodia: a multisite prospective cohort study. Lancet Infectious Diseases, 16, 357-365.

4. Amato R, Lim P, Miotto O, Amaratunga C, Dek D, Pearson RD, Almagro-Garcia J, Neal AT, Sreng S, Suon S, Drury E, Jyothi D, Stalker J, Kwiatkowski DP, Fairhurst RM. 2017. Genetic markers associated with dihydroartemisinin-piperaquine failure in Plasmodium falciparum malaria in Cambodia: a genotype-phenotype association study. Lancet Infectious Diseases, 17, 164-173.

5. Anderson TJ, Nair S, Nkhoma S, Williams JT, Imwong M, Yi P, Socheat D, Das D, Chotivanich K, Day NP, White NJ, Dondorp AM. 2010. High heritability of malaria parasite clearance rate indicates a genetic basis for artemisinin resistance in Western Cambodia. Journal of Infectious Diseases, 201, 1326-1330.

6. Ariey F, Witkowski B, Amaratunga C, Beghain J, Langlois AC, Khim N, Kim S, Duru V, Bouchier C, Ma L, Lim P, Leang R, Duong S, Sreng S, Suon S, Chuor CM, Bout DM, Ménard S, Rogers WO, Genton B, Fandeur T, Miotto O, Ringwald P, Le Bras J, Berry A, Barale JC, Fairhurst RM, Benoit-Vical F, Mercereau-Puijalon O, Ménard D. 2014. A molecular marker of artemisinin-resistant Plasmodium falciparum malaria. Nature, 505, 550.

7. Ataide R, Ashley EA, Powell R, Chan JA, Malloy MJ, O'Flaherty K, Takashima E, Langer C, Tsuboi T, Dondorp AM, Day NP, Dhorda M, Fairhurst RM, Lim P, Amaratunga C, Pukrittayakamee S, Hien TT, Htut Y, Mayxay M, Faiz MA, Beeson JG, Nosten F, Simpson JA, White NJ, Fowkes FJ. 2017. Host immunity to Plasmodium falciparum and the assessment of emerging artemisinin resistance in a multinational cohort. Proceedings of the National Academy of Sciences of the United States of America, 114, 3515-3520.

8. Ataíde R, Powell R, Moore K, McLean A, Phyo AP, Nair S, White M, Anderson TJ, Beeson JG, Simpson JA, Nosten F, Fowkes FJI. 2017. Declining transmission and immunity to malaria and emerging artemisinin resistance in Thailand: A longitudinal study. Journal of Infectious Diseases, 216, 723731.

9. Bhattacharjee S, Coppens I, Mbengue A, Suresh N, Ghorbal M, Slouka Z, Safeukui I, Tang HY, Speicher DW, Stahelin RV, Mohandas N, Haldar K. 2018. Remodeling of the malaria parasite and host human red cell by vesicle amplification that induces artemisinin resistance. Blood, doi: 10.1182/blood-2017-11-814665.

10. Brower V. 2017. Falsified and substandard malaria drugs in Africa. Lancet Infectious Diseases, 17, 1026-1027.

11. Brown TS, Jacob CG, Silva JC, Takala-Harrison S, Djimdé A, Dondorp AM, Fukuda M, Noedl H, Nyunt MM, Kyaw MP, Mayxay M, Hien TT, Plowe CV, Cummings MP. 2015. Plasmodium falciparum field isolates from areas of repeated emergence of drug resistant malaria show no evidence of hypermutator phenotype. Infection, Genetics Evolution, 30, 318-322.
12. Buffet PA, Safeukui I, Deplaine G, Brousse V, Prendki V, Thellier M, Turner GD, Mercereau-Puijalon O. 2011. The pathogenesis of Plasmodium falciparum malaria in humans: insights from splenic physiology. Blood, 117, 381-392.

13. Burki T. 2017. Ending malaria. Lancet Infectious Diseases, $17,28-29$

14. Cerqueira GC, Cheeseman IH, Schaffner SF, Nair S, McDew-White M, Phyo AP, Ashley EA, Melnikov A, Rogov P, Birren BW, Nosten F, Anderson TJC, Neafsey DE. 2017. Longitudinal genomic surveillance of Plasmodium falciparum malaria parasites reveals complex genomic architecture of emerging artemisinin resistance. Genome Biology, 18, 78

15. Chen N, LaCrue AN, Teuscher F, Waters NC, Gatton ML, Kyle DE, Cheng Q. 2014. Fatty acid synthesis and pyruvate metabolism pathways remain active in dihydroartemisinin-induced dormant ring stages of Plasmodium falciparum. Antimicrobial Agents and Chemotherapy, $58,4773-4781$.

16. Cooper RA, Hartwig CL, Ferdig MT. 2005. Pfcrt is more than the Plasmodium falciparum chloroquine resistance gene: a functional and evolutionary perspective. Acta Tropica, 94, 170-180.

17. Cui L, Su X. 2009. Discovery, mechanisms of action and combination therapy of artemisinin. Expert Review of Antiinfective Therapy, 7, 999-1013.

18. Dechy-Cabaret O, Benoit-Vical F. 2012. Effects of antimalarial molecules on the gametocyte stage of Plasmodium falciparum: The debate. Journal of Medicinal Chemistry, 55, 10328-10344.

19. Desjardins RE, Canfield CJ, Haynes JD, Chulay JD. 1979. Quantitative assessment of antimalarial activity in vitro by a semiautomated microdilution technique. Antimicrobial Agents and Chemotherapy, 16, 710-718.

20. Dipanjan B, Shivaprakash G, Balaji O. 2017. Triple combination therapy and drug cycling-tangential strategies for countering artemisinin resistance. Current Infectious Disease Reports, 19, 25

21. Dondorp AM, Fanello CI, Hendriksen IC, Gomes E, Seni A, Chhaganlal KD, Bojang K, Olaosebikan R, Anunobi N, Maitland K, Kivaya E, Agbenyega T, Nguah SB, Evans J, Gesase S, Kahabuka C, Mtove G, Nadjm B, Deen J, Mwanga-Amumpaire J, Nansumba M, Karema C, Umulisa N, Uwimana A, Mokuolu OA, Adedoyin OT, Johnson WB, Tshefu AK, Onyamboko MA, Sakulthaew T, Ngum WP, Silamut K, Stepniewska K, Woodrow CJ, Bethell D, Wills B, Oneko M, Peto TE, von Seidlein L, Day NP, White NJ, AQUAMAT group. 2010. Artesunate versus quinine in the treatment of severe falciparum malaria in African children (AQUAMAT): an open-label, randomised trial. Lancet, 376, 1647-1657.

22. Dondorp AM, Nosten F, Yi P, Das D, Phyo AP, Tarning J, Lwin KM, Ariey F, Hanpithakpong W, Lee SJ, Ringwald P, Silamut K, Imwong M, Chotivanich K, Lim P, Herdman T, An SS, Yeung S, Singhasivanon P, Day NP, Lindegardh N, Socheat D, White NJ. 2009. Artemisinin resistance in Plasmodium falciparum malaria. New England Journal of Medicine, 361, 455-467.

23. Dondorp AM, Smithuis FM, Woodrow C, Seidlein L von. 2017. How to contain artemisinin- and multidrug-resistant falciparum malaria. Trends in Parasitology, 33, 353-363.

24. Duru V, Khim N, Leang R, Kim S, Domergue A, Kloeung N, Ke S, Chy S, Eam R, Khean C, Loch K, Ken M, Lek D, Beghain J, Ariey F, Guerin PJ, Huy R, Mercereau-Puijalon O, Witkowski B, Menard D. 2015. Plasmodium falciparum dihydroartemisinin-piperaquine failures in Cambodia are associated with mutant K13 parasites presenting high 
survival rates in novel piperaquine in vitro assays: retrospective and prospective investigations. BMC Medecine, 13, 305 .

25. Echeverry DF, Holmgren G, Murillo C, Higuita JC, Björkman A, Gil JP, Osorio L. 2007. Short report: polymorphisms in the pfcrt and $p f m d r 1$ genes of Plasmodium falciparum and in vitro susceptibility to amodiaquine and desethylamodiaquine. American Journal of Tropical Medicine and Hygiene, 77, 1034-1038.

26. Fairhurst RM. 2015. Understanding artemisinin-resistant malaria: what a difference a year makes. Current Opinion in Infectious Diseases, 28, 417-425.

27. Gomes C, Boareto AC, Dalsenter PR. 2016. Clinical and non-clinical safety of artemisinin derivatives in pregnancy. Reproductive Toxicology, 65, 194-203.

28. Gregson A, Plowe CV. 2005. Mechanisms of resistance of malaria parasites to antifolates. Pharmacological reviews, $57,117-145$.

29. Imwong M, Suwannasin K, Kunasol C, Sutawong K, Mayxay M, Rekol H, Smithuis FM, Hlaing TM, Tun KM, van der Pluijm RW, Tripura R, Miotto O, Menard D, Dhorda M, Day NPJ, White NJ, Dondorp AM. 2017. The spread of artemisinin-resistant Plasmodium falciparum in the Greater Mekong subregion: a molecular epidemiology observational study. Lancet Infectious Diseases, 17, 491-497.

30. Kaur H, Clarke S, Lalani M, Phanouvong S, Guérin P, McLoughlin A, Wilson BK, Deats M, Plançon A, Hopkins H, Miranda D, Schellenberg D. 2016. Fake anti-malarials: start with the facts. Malaria Journal, 15, 86.

31. Kessl JJ, Meshnick SR, Trumpower BL. 2007. Modeling the molecular basis of atovaquone resistance in parasites and pathogenic fungi. Trends in Parasitology, 23, 494-501.

32. Kovacs SD, van Eijk AM, Sevene E, Dellicour S, Weiss NS, Emerson S, Steketee R, Ter Kuile FO, Stergachis A. 2016. The safety of artemisinin derivatives for the treatment of malaria in the 2nd or 3rd trimester of pregnancy: a systematic review and meta-analysis. PLoS One,11, e0164963.

33. Kublin JG, Cortese JF, Njunju EM, Mukadam RA, Wirima JJ, Kazembe PN, Djimdé AA, Kouriba B, Taylor TE, Plowe CV. 2003. Reemergence of chloroquine-sensitive Plasmodium falciparum malaria after cessation of chloroquine use in Malawi. Journal of Infectious Diseases, 187, 1870-1875.

34. Laufer MK, Takala-Harrison S, Dzinjalamala FK, Stine OC, Taylor TE, Plowe CV. 2010. Return of chloroquinesusceptible falciparum malaria in Malawi was a reexpansion of diverse susceptible parasites. Journal of Infectious Diseases, 202, 801-808.

35. Laufer MK, Thesing PC, Eddington ND, Masonga R, Dzinjalamala FK, Takala SL, Taylor TE, Plowe CV. 2006. Return of chloroquine antimalarial efficacy in Malawi. New England Journal of Medicine, 355, 1959-1966.

36. Laurent STB, Miller B, Burton TA, Amaratunga C, Men S, Sovannaroth S, Fay MP, Miotto O, Gwadz RW, Anderson JM, Fairhurst RM. 2015. Artemisinin-resistant Plasmodium falciparum clinical isolates can infect diverse mosquito vectors of Southeast Asia and Africa. Nature Communications, 6, 8614 .

37. Leang R, Barrette A, Bouth DM, Menard D, Abdur R, Duong S, Ringwald P. 2013. Efficacy of dihydroartemisininpiperaquine for treatment of uncomplicated Plasmodium falciparum and Plasmodium vivax in Cambodia, 2008 to 2010. Antimicrobial Agents and Chemotherapy, 57, 818826.

38. Leang R, Canavati SE, Khim N, Vestergaard LS, Borghini Fuhrer I, Kim S, Denis MB, Heng P, Tol B, Huy R, Duparc S, Dondorp AM, Menard D, Ringwald P. 2016. Efficacy and safety of Pyronaridine-Artesunate for treatment of uncomplicated Plasmodium falciparum malaria in Western Cambodia. Antimicrobial Agents and Chemotherapy, 60, 3884-3890.

39. Leang R, Taylor WR, Bouth DM, Song L, Tarning J, Char MC, Kim S, Witkowski B, Duru V, Domergue A, Khim N, Ringwald P, Menard D. 2015. Evidence of Plasmodium falciparum malaria multidrug resistance to artemisinin and piperaquine in Western Cambodia: DihydroartemisininPiperaquine open-label multicenter clinical assessment. Antimicrobial Agents and Chemotherapy, 59, 4719-4726.

40. Lee AH, Fidock DA. 2016. Evidence of a mild mutator phenotype in Cambodian Plasmodium falciparum malaria parasites. PloS One, 11, e0154166.

41. Lu F, Culleton R, Zhang M, Ramaprasad A, von Seidlein L, Zhou H, Zhu G, Tang J, Liu Y, Wang W, Cao Y, Xu S, Gu Y, Li J, Zhang C, Gao Q, Menard D, Pain A, Yang H, Zhang Q, Cao J. 2017. Emergence of indigenous artemisinin-resistant Plasmodium falciparum in Africa. New England Journal of Medicine, 376, 991-993.

42. Lubell Y, Dondorp A, Guérin PJ, Drake T, Meek S, Ashley E, Day NP, White NJ, White LJ. 2014. Artemisinin resistance-modelling the potential human and economic costs. Malaria Journal, 13, 452.

43. Ménard D, Khim N, Beghain J, Adegnika AA ${ }^{1}$ Shafiul-Alam M, Amodu O, Rahim-Awab G, Barnadas C, Berry A, Boum Y, Bustos MD, Cao J, Chen JH, Collet L, Cui L, Thakur GD, Dieye A, Djallé D, Dorkenoo MA, Eboumbou-Moukoko CE, Espino FE, Fandeur T, Ferreira-da-Cruz MF, Fola AA, Fuehrer HP, Hassan AM, Herrera S, Hongvanthong B, Houzé S, Ibrahim ML, Jahirul-Karim M, Jiang L, Kano S, Ali-Khan W, Khanthavong M, Kremsner PG, Lacerda M, Leang R, Leelawong M, Li M, Lin K, Mazarati JB, Ménard S, Morlais I, Muhindo-Mavoko H, Musset L, Na-Bangchang K, Nambozi M, Niaré K, Noedl H, Ouédraogo JB, Pillai DR, Pradines B, Quang-Phuc B, Ramharter M, Randrianarivelojosia M, Sattabongkot J, Sheikh-Omar A, Silué KD, Sirima SB, Sutherland C, Syafruddin D, Tahar R, Tang LH, Touré OA, Tshibangu-wa-Tshibangu P, Vigan-Womas I, Warsame M, Wini L, Zakeri S, Kim S, Eam R, Berne L, Khean C, Chy S, Ken M, Loch K, Canier L, Duru V, Legrand E, Barale JC, Stokes B, Straimer J, Witkowski B, Fidock DA, Rogier C, Ringwald P, Ariey F, Mercereau-Puijalon O, KARMA Consortium. 2016. A Worldwide map of Plasmodium falciparum K13-propeller polymorphisms. New England Journal of Medicine, 374, 2453-2464.

44. Ménard S, Ben Haddou T, Ramadani AP, Ariey F, Iriart X, Beghain J, Bouchier C, Witkowski B, Berry A, MercereauPuijalon O, Benoit-Vical F. 2015. Induction of multidrug tolerance in Plasmodium falciparum by extended artemisinin pressure. Emerging Infectious Diseases, 21, 1733-1741.

45. Miotto O, Amato R, Ashley EA, MacInnis B, AlmagroGarcia J, Amaratunga C, Lim P, Mead D, Oyola SO, Dhorda M, Imwong M, Woodrow C, Manske M, Stalker J, Drury E, Campino S, Amenga-Etego L, Thanh TN, Tran HT, Ringwald P, Bethell D, Nosten F, Phyo AP, Pukrittayakamee S, Chotivanich K, Chuor CM, Nguon C, Suon S, Sreng S, Newton PN, Mayxay M, Khanthavong M, Hongvanthong B, Htut Y, Han KT, Kyaw MP, Faiz MA, Fanello CI, Onyamboko M, Mokuolu OA, Jacob CG, Takala-Harrison S, Plowe CV, Day NP, Dondorp AM, Spencer CC, McVean G, Fairhurst RM, White NJ, Kwiatkowski DP. 2015. Genetic architecture of artemisininresistant Plasmodium falciparum. Nature Genetics, 47, 226.

46. Mita T, Tanabe K, Kita K. 2009. Spread and evolution of Plasmodium falciparum drug resistance. Parasitology International, 58, 201-209. 
47. MMV-supported projects: Medicines for Malaria Venture. https://www.mmv.org/research-development/mmv-sup ported-projects.

48. Mungthin M, Khositnithikul R, Sitthichot N, Suwandittakul N, Wattanaveeradej V, Ward SA, Na-Bangchang K. 2010. Association between the pfmdr1 gene and in vitro artemether and lumefantrine sensitivity in Thai isolates of Plasmodium falciparum. American Journal of Tropical Medicine and Hygiene, 83, 1005-1009.

49. Mwanza S, Joshi S, Nambozi M, Chileshe J, Malunga P, Kabuya JB, Hachizovu S, Manyando C, Mulenga M, Laufer M. 2016. The return of chloroquine-susceptible Plasmodium falciparum malaria in Zambia. Malaria Journal, 15, 584.

50. Na-Bangchang K, Muhamad P, Ruaengweerayut R, Chaijaroenkul W, Karbwang J. 2013. Identification of resistance of Plasmodium falciparum to artesunate-mefloquine combination in an area along the Thai-Myanmar border: integration of clinico-parasitological response, systemic drug exposure, and in vitro parasite sensitivity. Malaria Journal, 12, 263.

51. Ndour PA, Lopera-Mesa TM, Diakité SA, Chiang S, Mouri O, Roussel C, Jauréguiberry S, Biligui S, Kendjo E, Claessens A, Ciceron L, Mazier D, Thellier M, Diakité M, Fairhurst RM, Buffet PA. 2015. Plasmodium falciparum clearance is rapid and pitting independent in immune Malian children treated with artesunate for malaria. Journal of Infectious Diseases, 211, 290-297.

52. Newton PN, Hanson K, Goodman C. 2017. Do antimalarials in Africa meet quality standards? The market penetration of non quality-assured artemisinin combination therapy in eight African countries. Malaria Journal, 16, 204.

53. Noedl H, Se Y, Schaecher K, Smith BL, Socheat D, Fukuda MM. 2008. Evidence of artemisinin-resistant malaria in Western Cambodia. New England Journal of Medicine, 359, 2619-2620.

54. Ogouyèmi-Hounto $A$, Damien $G$, Deme $A B$, Ndam NT, Assohou C, Tchonlin D, Mama A, Hounkpe VO, Moutouama JD, Remoué F, Ndiaye D, Gazard DK. 2016. Lack of artemisinin resistance in Plasmodium falciparum in northwest Benin after 10 years of use of artemisinin-based combination therapy. Parasite, 23, 28.

55. Paloque L, Ramadani AP, Mercereau-Puijalon O, Augereau J-M, Benoit-Vical F. 2016. Plasmodium falciparum: multifaceted resistance to artemisinins. Malaria Journal, 15, 149.

56. Paloque L, Witkowski B, Lelièvre J, Ouji M, Ben Haddou T, Ariey F, Robert A, Augereau JM, Ménard D, Meunier B, Benoit-Vical F. 2018. Endoperoxide-based compounds: cross-resistance with artemisinins and selection of a Plasmodium falciparum lineage with a K13 non-synonymous polymorphism. Journal of Antimicrobial Chemotherapy, 73, 395-403.

57. Peatey CL, Chavchich M, Chen N, Gresty KJ, Gray KA, Gatton ML, Waters NC, Cheng Q. 2015. Mitochondrial membrane potential in a small subset of artemisinininduced dormant Plasmodium falciparum parasites in vitro. Journal of Infectious Diseases, 212, 426-434.

58. Phompradit P, Muhamad P, Chaijaroenkul W, Na-Bangchang K. 2014. Genetic polymorphisms of candidate markers and in vitro susceptibility of Plasmodium falciparum isolates from Thai-Myanmar border in relation to clinical response to artesunate-mefloquine combination. Acta Tropica, 139, 77-83.

59. Phuc BQ, Rasmussen C, Duong TT, Dong LT, Loi MA, Ménard D, Tarning J, Bustos D, Ringwald P, Galappaththy GL, Thieu NQ. 2017. Treatment failure of dihydroartemisinin/piperaquine for Plasmodium falciparum malaria, Vietnam. Emerging Infectious Diseases, 23, 715-717.
60. Phyo AP, Ashley EA, Anderson TJC, Bozdech Z, Carrara VI, Sriprawat K, Nair S, White MM, Dziekan J, Ling C, Proux S, Konghahong K, Jeeyapant A, Woodrow CJ, Imwong M, McGready R, Lwin KM, Day NPJ, White NJ, Nosten F. 2016. Declining efficacy of artemisinin combination therapy against $P$. falciparum malaria on the ThaiMyanmar border (2003-2013): The role of parasite genetic factors. Clinical Infectious Diseases, 63, 784-791.

61. Phyo AP, Jittamala P, Nosten FH, Pukrittayakamee S, Imwong M, White NJ, Duparc S, Macintyre F, Baker M, Möhrle JJ. 2016. Antimalarial activity of artefenomel (OZ439), a novel synthetic antimalarial endoperoxide, in patients with Plasmodium falciparum and Plasmodium vivax malaria: an open-label phase 2 trial. Lancet Infectious Diseases, 16, 61-69.

62. Phyo AP, Nkhoma S, Stepniewska K, Ashley EA, Nair S, McGready R, ler Moo C, Al-Saai S, Dondorp AM, Lwin KM, Singhasivanon P, Day NP, White NJ, Anderson TJ, Nosten F. 2012. Emergence of artemisinin-resistant malaria on the western border of Thailand: a longitudinal study. The Lancet, 379, 1960-1966.

63. Phyo AP, Win KK, Thu AM, Swe LL, Htike H, Beau C, Sriprawat K, Winterberg M, Proux S, Imwong M, Ashley EA, Nosten F. 2018. Poor response to artesunate treatment in two patients with severe malaria on the Thai-Myanmar border. Malaria Journal, 17, 30.

64. Price RN, Uhlemann AC, Brockman A, McGready R, Ashley E, Phaipun L, Patel R, Laing K, Looareesuwan S, White NJ, Nosten F, Krishna S. 2004. Mefloquine resistance in Plasmodium falciparum and increased $p f m d r 1$ gene copy number. Lancet, 364, 438-447.

65. Price RN, Uhlemann AC, van Vugt M, Brockman A, Hutagalung R, Nair S, Nash D, Singhasivanon P, Anderson TJ, Krishna S, White NJ, Nosten F. 2006. Molecular and pharmacological determinants of the therapeutic response to artemether-lumefantrine in multidrug-resistant Plasmodium falciparum malaria. Clinical Infectious Diseases, 42, 1570-1577.

66. Renschler JP, Walters KM, Newton PN, Laxminarayan R. 2015. Estimated under-five deaths associated with poorquality antimalarials in Sub-Saharan Africa. American Journal of Tropical Medicine and Hygiene, 92, 119-126.

67. Robert A, Benoit-Vical F, Claparols C, Meunier B. 2005. The antimalarial drug artemisinin alkylates heme in infected mice. Proceedings of the National Academy of Sciences. 102, 13676-13680.

68. Saunders DL, Vanachayangkul P, Lon C. Dihydroartemisinin-piperaquine failure in Cambodia. 2014. New England Journal of Medicine, 371, 484-485.

69. Slater HC, Griffin JT, Ghani AC, Okell LC. 2016. Assessing the potential impact of artemisinin and partner drug resistance in sub-Saharan Africa. Malaria Journal, 15, 10.

70. Somé AF, Sorgho H, Zongo I, Bazié T, Nikiéma F, Sawadogo A, Zongo M, Compaoré YD, Ouédraogo JB. 2016. Polymorphisms in K13, pfcrt, pfmdr1, pfdhfr, and pfdhps in parasites isolated from symptomatic malaria patients in Burkina Faso. Parasite, 23, 60.

71. Spring MD, Lin JT, Manning JE, Vanachayangkul P, Somethy S, Bun R, Se Y, Chann S, Ittiverakul M, Sia-ngam P, Kuntawunginn W, Arsanok M, Buathong N, Chaorattanakawee S, Gosi P, Ta-aksorn W, Chanarat N, Sundrakes S, Kong N, Heng TK, Nou S, Teja-isavadharm P, Pichyangkul S, Phann ST, Balasubramanian S, Juliano JJ, Meshnick SR, Chour CM, Prom S, Lanteri CA, Lon C, Saunders DL. 2015. Dihydroartemisinin-piperaquine failure associated with a triple mutant including kelch13 C580Y in Cambodia: an observational cohort study. Lancet Infectious Diseases, 15, 683-691. 
72. Straimer J, Gnädig NF, Stokes BH, Ehrenberger M, Crane AA, Fidock DA. 2017. Plasmodium falciparum K13 mutations differentially impact ozonide susceptibility and parasite fitness in vitro. $\mathrm{mBio}, 8$, e00172-17.

73. Straimer J, Gnädig NF, Witkowski B, Amaratunga C, Duru V, Ramadani AP, Dacheux M, Khim N, Zhang L, Lam S, Gregory PD, Urnov FD, Mercereau-Puijalon O, BenoitVical F, Fairhurst RM, Ménard D, Fidock DA. 2015. Drug resistance. K13-propeller mutations confer artemisinin resistance in Plasmodium falciparum clinical isolates. Science, $347,428-431$.

74. Takala-Harrison S, Clark TG, Jacob CG, Cummings MP, Miotto O, Dondorp AM, Fukuda MM, Nosten F, Noedl H, Imwong M, Bethell D, Se Y, Lon C, Tyner SD, Saunders DL, Socheat D, Ariey F, Phyo AP, Starzengruber P, Fuehrer HP, Swoboda P, Stepniewska K, Flegg J, Arze C, Cerqueira GC, Silva JC, Ricklefs SM, Porcella SF, Stephens RM, Adams M, Kenefic LJ, Campino S, Auburn S, MacInnis B, Kwiatkowski DP, Su XZ, White NJ, Ringwald P, Plowe CV. 2013. Genetic loci associated with delayed clearance of Plasmodium falciparum following artemisinin treatment in Southeast Asia. Proceedings of the National Academy of Sciences, 110, 240-245.

75. Takala-Harrison S, Jacob CG, Arze C, Cummings MP, Silva JC, Dondorp AM, Fukuda MM, Hien TT, Mayxay M, Noedl H, Nosten F, Kyaw MP, Nhien NT, Imwong M, Bethell D, Se Y, Lon C, Tyner SD, Saunders DL, Ariey F, MercereauPuijalon O, Menard D, Newton PN, Khanthavong M, Hongvanthong B, Starzengruber P, Fuehrer HP, Swoboda P, Khan WA, Phyo AP, Nyunt MM, Nyunt MH, Brown TS, Adams M, Pepin CS, Bailey J, Tan JC, Ferdig MT, Clark TG, Miotto O, MacInnis B, Kwiatkowski DP, White NJ, Ringwald P, Plowe CV. 2015. Independent emergence of artemisinin resistance mutations among Plasmodium falciparum in Southeast Asia. Journal of Infectious Diseases, $211,670-679$.

76. Thanh NV, Thuy-Nhien N, Tuyen NT, Tong NT, Nha-Ca NT, Dong LT, Quang HH, Farrar J, Thwaites G, White NJ, Wolbers M, Hien TT. 2017. Rapid decline in the susceptibility of Plasmodium falciparum to dihydroartemisininpiperaquine in the south of Vietnam. Malaria Journal, 16, 27.

77. Thu AM, Phyo AP, Landier J, Parker DM, Nosten FH. 2017. Combating multidrug-resistant Plasmodium falciparum malaria. FEBS Journal, 284, 2569-2578.

78. White N. 2011. The parasite clearance curve. Malaria Journal, 10, 278.

79. WHO. 2017. World malaria report 2017. http://www.who. int/malaria/publications/world-malaria-report-2017/re port $/$ en $/$.

80. WHO. April 2017. Status report on artemisinin and ACT resistance. http://www.who.int/malaria/publications/ atoz/artemisinin-resistance-april2017/en/.

81. WHO. September 2015. Status report on artemisinin and ACT resistance. http://www.who.int/malaria/publica tions/atoz/update-artemisinin-resistance-sep2015/en/.
82. WHO. 2014. World Malaria Report 2014. http://www.who. int/malaria/publications/world malaria report 2014/en/.

83. Witkowski B, Duru V, Khim $\bar{N}$, Ross $\bar{L} S$, Saintpierre B, Beghain J, Chy S, Kim S, Ke S, Kloeung N, Eam R, Khean C, Ken M, Loch K, Bouillon A, Domergue A, Ma L, Bouchier C, Leang R, Huy R, Nuel G, Barale JC, Legrand E, Ringwald P, Fidock DA, Mercereau-Puijalon O, Ariey F, Ménard D. 2017. A surrogate marker of piperaquineresistant Plasmodium falciparum malaria: a phenotypegenotype association study. Lancet Infectious Diseases, 17, $174-183$.

84. Witkowski B, Khim N, Chim P, Kim S, Ke S, Kloeung N, Chy S, Duong S, Leang R, Ringwald P, Dondorp AM, Tripura R, Benoit-Vical F, Berry A, Gorgette O, Ariey F, Barale JC, Mercereau-Puijalon O, Menard D. 2013. Reduced artemisinin susceptibility of Plasmodium falciparum ring stages in Western Cambodia. Antimicrobial Agents and Chemotherapy, 57, 914-23.

85. Witkowski B, Lelièvre J, Barragán MJ, Laurent V, Su XZ, Berry A, Benoit-Vical F. 2010. Increased tolerance to artemisinin in Plasmodium falciparum is mediated by a quiescence mechanism. Antimicrobial Agents and Chemotherapy, 54, 1872-1877.

86. Wongsrichanalai C, Meshnick SR. 2008. Declining artesunate-mefloquine efficacy against falciparum malaria on the Cambodia-Thailand border. Emerging Infectious Diseases, 14, 716-719.

87. WWARN Artemisinin based Combination Therapy (ACT) Africa Baseline Study Group, Dahal P, d'Alessandro U, Dorsey G, Guerin PJ, Nsanzabana C, Price RN, Sibley CH, Stepniewska K, Talisuna AO. 2015. Clinical determinants of early parasitological response to ACTs in African patients with uncomplicated falciparum malaria: a literature review and meta-analysis of individual patient data. BMC Medicine, 13, 212.

88. WWARN Parasite Clearance Study Group, Abdulla S, Ashley EA, Bassat Q, Bethell D, Björkman A, Borrmann S, D'Alessandro U, Dahal P, Day NP, Diakite M, Djimde AA, Dondorp AM, Duong S, Edstein MD, Fairhurst RM, Faiz MA, Falade C, Flegg JA, Fogg C, Gonzalez R, Greenwood B, Guérin PJ, Guthmann JP, Hamed K, Hien TT, Htut Y, Juma E, Lim P, Mårtensson A, Mayxay M, Mokuolu OA, Moreira C, Newton P, Noedl H, Nosten F, Ogutu BR, Onyamboko MA, Owusu-Agyei S, Phyo AP, Premji Z, Price RN, Pukrittayakamee S, Ramharter M, Sagara I, Se Y, Suon S, Stepniewska K, Ward SA, White NJ, Winstanley PA. 2015. Baseline data of parasite clearance in patients with falciparum malaria treated with an artemisinin derivative: an individual patient data meta-analysis. Malaria Journal, 14,359 .

89. Yang T, Xie SC, Cao P, Giannangelo C, McCaw J, Creek DJ, Charman SA, Klonis N, Tilley L. 2016. Comparison of the exposure time dependence of the activities of synthetic ozonide antimalarials and dihydroartemisinin against K13 Wild-Type and mutant Plasmodium falciparum strains. Antimicrobial Agents and Chemotherapy, 60, 4501-4510. 
O PARASTE

An international open-access, peer-reviewed, online journal publishing high quality papers on all aspects of human and animal parasitology

Reviews, articles and short notes may be submitted. Fields include, but are not limited to: general, medical and veterinary parasitology; morphology, including ultrastructure; parasite systematics, including entomology, acarology, helminthology and protistology, and molecular analyses; molecular biology and biochemistry; immunology of parasitic diseases; host-parasite relationships; ecology and life history of parasites; epidemiology; therapeutics; new diagnostic tools.

All papers in Parasite are published in English. Manuscripts should have a broad interest and must not have been published or submitted elsewhere. No limit is imposed on the length of manuscripts.

Parasite (open-access) continues Parasite (print and online editions, 1994-2012) and Annales de Parasitologie Humaine et Comparée (1923-1993) and is the official journal of the Société Française de Parasitologie. 